\title{
ACCREDITATION, LICENSING, AND SPECIALIZATION FOR EMPLOYMENT
}

\author{
Jim Graham and Marolo Alfaro \\ University of Manitoba, Winnipeg, Manitoba \\ jgraham@cc.umanitoba.ca
}

\begin{abstract}
The Canadian Engineering Accreditation Board directs undergraduate programs towards a broadly based education in engineering. Employers accept the need for a broad education but also want young engineers to have specialist training for practice. These very different requirements appear at first sight to be in conflict.

In the United States and Europe, but not yet in Canada, licensing bodies are moving towards requiring a master's degree or equivalent for licensing. Companies that engage in international projects are concerned they may be unable to compete if other countries require master's degrees for licensing, while Canada does not.

Universities should develop broad educational undergraduate programs that can actually be completed in four years in principal areas like civil, electrical, mechanical engineering. Additional effort should be directed towards specialist master's programs that provide training for employability.
\end{abstract}

Keywords: Accreditation, education, licensing, training, specialization, employability.

\section{INTRODUCTION INTRODUCTION - REGULATORY FRAMEWORK}

Engineering graduates want to become licensed as professional engineers and be able to work independently. To achieve a licence, a candidate must first graduate from an accredited university program (see for example Engineers Canada [8] and ABET [1]). In many countries, graduates then require additional years of directed experience under the guidance of an engineer supervisor. We begin by reviewing the regulatory framework for accreditation and its implications for developing broadly based but also specialized engineers who are needed in many of the specialty areas of engineering.

Accreditation of undergraduate engineering programs now directs less attention to curriculum assessment what is being taught - and closer attention to outcomes what is being learned.
For example, Table 1 shows Learning Outcomes, Attributes, and Competency Levels that can be expected from graduates from an accredited undergraduate engineering program in Canada.

Table 1: Learning outcomes required by $C E A B$

\section{Learning Outcomes:}

1. Synthesize the broad understanding of geology and material properties that can be used for designing solutions to geotechnical engineering projects.

2. Plan, interpret and examine field investigation/laboratory testing programs to obtain the necessary soil and site information.

3. Design geotechnical infrastructure including shallow foundations, deep foundations, excavations, embankments, dams, earth retaining structures and remediation of engineered and natural slopes.

\section{*Attributes}

A1 A knowledge base for engineering

A2 Problem analysis

A3 Investigation

A4 Design

A5 Use of engineering tools

A6 Individual and team work

A7 Communication skills

A8 Professionalism

A9 Impact of engineering on society/ environment

A10 Ethics and equity

A11 Economics and project management

A12 Life-long learning

\section{**Competency Level}

1 Ability to recall (knowledge)

2 Ability to rephrase information (comprehension)

3 Ability to apply knowledge in a new situation (application)

4 Ability to break problem into its constituent parts, and establish relationship (analysis)

5 Ability to combine separate elements into whole (synthesis)

6 Ability to make judgment of the worth of something (evaluation) 
Table 2. CIVL 4220 Geotechnical Design: Expected Competency Level**

\begin{tabular}{c|c|c|c|c|c|c|c|c|c|c|c|c}
\hline $\begin{array}{c}\text { Learning } \\
\text { Outcome }\end{array}$ & \multicolumn{10}{c}{ Attribute* } \\
\hline & A1 & A2 & A3 & A4 & A5 & A6 & A7 & A8 & A9 & A10 & A11 & A12 \\
\hline O1 & 5 & 5 & 5 & 5 & 5 & 3 & 3 & 3 & 3 & 2 & 4 & 3 \\
\hline O2 & 5 & 5 & 6 & 5 & 5 & 3 & 3 & 3 & 3 & 2 & 4 & 3 \\
\hline O3 & 5 & 5 & 5 & 6 & 6 & 3 & 3 & 3 & 3 & 2 & 5 & 3 \\
\hline
\end{tabular}

Table 3. Evaluation

\begin{tabular}{|c|c|c|c|}
\hline Component & $\begin{array}{c}\text { Value } \\
\text { (\%) }\end{array}$ & $\begin{array}{c}\text { Methods } \\
\text { of } \\
\text { Feedback }\end{array}$ & $\begin{array}{l}\text { Learning } \\
\text { Outcomes } \\
\text { Evaluated }\end{array}$ \\
\hline Assignments & 10 & $\mathrm{~F}, \mathrm{~S}$ & O1-O3 \\
\hline Group Project & 10 & S,R & O1-O3 \\
\hline Term Test & 30 & $\mathrm{~F}, \mathrm{~S}$ & O1-03 \\
\hline $\begin{array}{c}\text { Final } \\
\text { Examination }\end{array}$ & 50 & $\mathrm{~S}$ & O1-O3 \\
\hline \multicolumn{4}{|c|}{$\begin{array}{l}\text { F - formative (written comments) } \\
\text { S - summative (number grades) } \\
\mathrm{R} \text { - rubrics (emphasizing important elements and how } \\
\text { well demonstrated) }\end{array}$} \\
\hline
\end{tabular}

Tables 2 and 3 shows our internal assessment of how one of our geotechnical courses at the University of Manitoba meets the Learning Outcomes requirements outlined in Table 1. The assessment has been prepared for an upcoming accreditation inspection by the CEAB.

Kellar et al. [15] defined objectives for an integrated program of engineering, mathematics and science:

1. Improved problem solving skills, critical thinking skills, and communication skills compared to a traditional engineering and science curriculum

2. Increased ability to integrate and appropriately apply technical skills with the fundamentals of math and science

3. Increased ability to participate in effective teams

4. Increased competence in applying technology for effective analysis, design, and communication

5. Increased motivation for self-responsibility, life-long learning, and self-development of a person of good character.

All of these are important and valuable objectives.

At the same time, we must accept that specialty areas such as geotechnical engineering in the broader discipline of civil engineering simply cannot be covered in sufficient detail to prepare graduates for consulting practice. Post-bachelor training is also needed. The question is how this should be done effectively.

In the United States, Britain, Europe, and Australia, accreditation bodies are moving towards undergraduate programs that strengthen students' abilities in problem solving (Canadian Academy of Engineering, [7]; Institution of Engineers, Australia [14]; SARTOR [23]).

In Canada, the Canadian Engineering Accreditation Board (CEAB) requires an emphasis on design in most engineering subject areas (Alfaro et al. [2]). It also requires multi-disciplinary capstone projects that are worked on by teams of students and are largely selflearned, with professors or practising engineers acting as mentors. These are important skills.

The Washington Accord in North America and the Bologna Accord in Europe recognize other countries' accreditation systems as being "substantially equivalent" without infringing on the respective jurisdictions. The accords may lead to university programs of four, five, or in some cases even six years.

In response, universities and licensing bodies in many countries are moving towards a three-stage approach - a broadly-based engineering education in first-degree programs, more specialized training in subsequent postgraduate programs, and a third stage of directed experience in practice (Turner [26]).

The United Kingdom has a 3-year bachelor program, and a further year leading to an MEng degree for students who wish to eventually become licensed. (The UK has higher academic requirements for university entrance.) A memorandum submitted by the Institution of Civil Engineers [13] in London to the UK Parliament includes the following comment: "... the four year integrated undergraduate MEng program (in the UK) sits uncomfortably between the first and second cycles (stages) of degree as defined by the Bologna Accord".

In the United States, ASCE documents [4] indicate that licensing may require 6 years of academic study as well as a further three or more years of "progressive, structured engineering experience":

"Admission to the practice of civil engineering at the professional level means professional engineering licensure requiring attainment of a Body of Knowledge through appropriate engineering education, experience and examinations. Fulfillment of this Body of Knowledge will typically include a combination of: 
1. a baccalaureate degree in civil engineering;

2. a master's degree, or approximately 30 coordinated graduate or upper level undergraduate technical and/or professional practice credits or the equivalent agency/organization/ professional society courses providing equal academic quality and rigor; and

3. appropriate experience based upon broad technical and professional practice guidelines which provide sufficient flexibility for a wide range of roles in engineering practice."

The authors regret that Engineers Canada, has not yet participated actively in this movement (Bilanski [5], Turner [26]). This lack of action may have implications for Canadian participation in international projects, especially since the 'working degree' in many branches of civil engineering, especially in geotechnical engineering, is already a master's degree (Alfaro et al. [2]).

\section{THE EDUCATIONAL FRAMEWORK}

A broad undergraduate program in civil engineering generally contains a number of specialty areas like water resources, structures, environmental engineering, geotechnical engineering, and transportation engineering. In the general curriculum required by the $\mathrm{CEAB}$, which we support, there is usually insufficient time to bring students to a level that would allow them to be considered 'specialists'. Yet consulting companies need and want specialists - this is the nature of practice in many areas of engineering. Employers, and therefore employees, need both generalized education and specialized training.

At postgraduate level, many courses contain material that reflects the professor's interests. They are often treated as preparation for those students who chose to undertake doctoral studies and research. They seldom seem aimed at the specialization that young engineers need for employment. We have heard from colleagues that such courses would lack intellectual rigour and attention to fundamentals. We disagree. With care, rigour can be retained and learning stimulated. Knowledge of fundamentals is important because they are needed for future learning and professional development. However, a reactionary emphasis on 'back to basics' is not acceptable - we must go 'forward to the basics'.

\section{IN THE CLASSROOM - UNDER- GRADUATE PROGRAMS}

Our experience and informal contacts suggest that most teaching in university classrooms is still 'chalk and talk', even if overheads or digital projectors are increasingly used. Professors deliver their course material to relatively large classes in single-discipline subjects. Students sit passively, copying from the board (or screen), reading, working on homework from another class, or daydreaming (Mills and Tregaust [18]). Currently, smart phones provide welcome distraction.

Employers commonly want more technical skills in more topic areas. Students speak of the large amount of course material that must be already be learned and how it is difficult to develop self-motivated learning skills for their ongoing professional development.

A tightly packed curriculum may not improve the quality of the educational experience (Engineers Canada [8]). Many current engineering programs are designed to last four years but typically take five. This level of consistent over-shooting design targets would be unacceptable in any other branch of engineering practice.

'More' is not necessarily 'better'; 'better' is 'better' (Alfaro et al. [2]). As with apple trees and rose bushes, pruning can produce renewed vigour. The objective of pruning course material is twofold. It removes deadwood from courses and allows growth of new material that we can consider 'basic'. The principal goal in improving undergraduate programs should be to improve selflearning skills and encourage specialization in subsequent master's programs.

Some years ago in the University of Manitoba, we asked our colleagues how we could improve the undergraduate program. The replies [10] included the following.

- 'The quality of our program is determined not by what we attempt to teach, but by what our students learn.'

- $\quad$ 'Students learn more and are more highly motivated when they are actively involved in the learning process.'

- 'Our graduates must expect the unexpected. Education will be a continuous process throughout their careers. Details will matter less; skills and attitudes will matter more.

Alfaro et al. [2] enlarged on these replies with more specific proposals for rejuvenating geotechnical engineering education. They emphasized the need for 'breadth' in undergraduate programs and 'skills-based learning' in postgraduate programs aimed at employability. A separate paper to this conference (Graham and Kurz [12]) comes from the authors' experience in teaching and researching as geotechnical engineers. We believe the insights learned from this experience are relevant to other branches of engineering.

The 'basics' of 1980 or 2000 are not the basics of 2012 - or 2020. 'Back to basics' is not an acceptable option. In Figure 1, Burland [6] listed the fundamental components that are inherent in every geotechnical project - (a) the need to understand the geology and variability of the ground, (b) the constitutive behaviour of 
earth materials that will be affected by the project and (c) the mathematical tools and techniques that can be used to analyse the problem. While these components remain valid, the basics of these components have changed in recent years. Obviously the geology of project sites has not changed, but the way in which information is collected and interpreted certainly has changed. Modern understanding of soil properties has advanced significantly from Burland's presentation in 1987 and is now included in many undergraduate courses. Examples include elastic-plastic modeling in the form of Modified Cam Clay. Similarly the use of computer solutions for stress-deformation, seepage, and slope stability has transformed analysis of geotechnical problems, which used to be solely based on closed-form solutions, with their associated restrictions and simplifications.

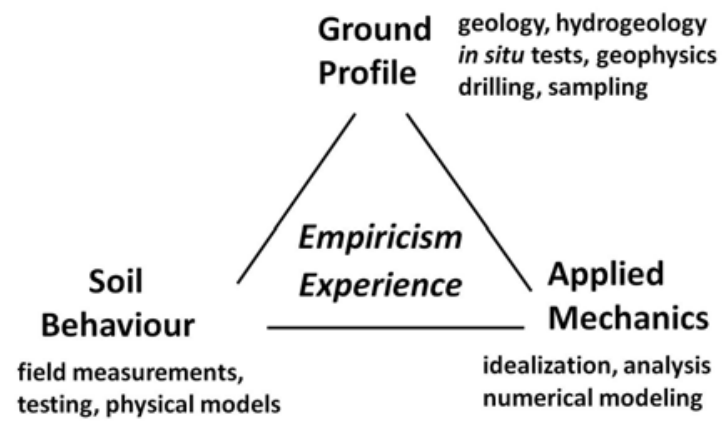

Fig. 1. Components inherent in all geotechnical engineering projects [6].

Employers know that graduates from current engineering programs generally understand fundamental engineering science quite well and are computer literate. However, they are less competent - or confident - which is perhaps more important - in putting their knowledge into practice. The lecture-style of teaching is not particularly well-suited to learning how to be an effective team-player on a large interdisciplinary project, or how to engage effectively in ongoing professional development.

The following section examines ways of developing better technical, learning, and professional skills.

\section{PROBLEM-BASED LEARNING}

Medical education commonly uses an approach known as Problem-Based Learning (PBL). In a time before gender equality, William Osler, an early leader in Canadian medical education, said that learning is a lifelong process and that 'we can only instill principles, put the student on the right path, give him methods, teach him how to study, and early to discern between essentials and non-essentials' [17]. These ideals were used at the Harvard School of Business, and were developed more fully in the undergraduate medical program at McMaster
University in Ontario, Canada [24]. The McMaster model has since been adopted by many health care schools. Instead of the standard building-block structure that feeds lots of content which students tend not to retain, it adopts a system in which students are actively involved in learning. In its purest form, it involves the following assumptions (Saarinen-Rahiika and Binkley [22]).

1. Students can be responsible for the breadth and depth of learning if given direction, resources and feedback.

2. Students bring with them a wide background of prior learning and experience.

3. Learning in small groups enhances understanding, exploration, discussion, and debate.

4. Faculty tutors facilitate learning and translate concepts rather than 'teach' or serve solely as information givers.

5. Information used to comprehend and deal with reallife scenarios is integrated from a variety of traditional disciplines.

There is also an expectation of increased retention of information, greater ability to apply knowledge in clinical contexts, and development of lifelong learning habits.

Lee and Kwan [17] showed that graduates from the McMaster medical program, a) enjoyed their education, b) consider themselves well-prepared for the next phase of their education, c) are sought after by program directors, d) perform well in licensing examinations, e) compare favourably with graduates from traditional programs, and f) show some interesting differences in behaviour in practice.

Students and graduates of PBL programs have good understanding of professional behaviour, including resource use and keeping up-to-date with the literature. However, the model requires increased expenditure of resources and time, both by the students and by the institution. There is also evidence that it may not produce improved levels of content-specific knowledge or problem-solving skills. These deficits have been overcome to a large extent by an approach known as Evidence-based Medicine, see http://ktclearinghouse.ca/cebm/intro/whatisebm. We note, too, that medical education usually follows pre-medical training in fundamental sciences, which is most often given in a classical 'chalk and talk' format.

\section{PROJECT-BASED LEARNING IN ENGINEERING}

Engineering programs that have adopted elements of PBL often use a 'middle ground' or 'hybrid' approach between conventional curricula and PBL [18]. This allows them to capitalize on the most valuable features of each. In these cases, which appear to be mostly, but not exclusively in civil engineering, PBL is used in individual 
courses within a traditional engineering program and not in the program as a whole.

This may relate to the nature of engineering knowledge and practice compared with medicine. Feletti [9] touched on this in the context of engineering when he described "another genre of professions...where problematic topics or situations loosely define the subject matter and where professional practice is typically not the process of solving well-defined problems". Medical knowledge is essentially encyclopaedic in nature [20]. In contrast, engineers use a hierarchical knowledge structure in which topics must be learned in a defined order because missing essential parts results in failure to learn later concepts.

Problems that engineers encounter in practice are usually different from those they worked on previously [21]. Almost every task undertaken in engineering practice involves a project that relates in some way to fundamental theories and techniques in the area of specialization. 'Projects' usually involve teams with a range of specializations. They will typically require days or months of work by teams of individuals, rather than the minutes or hours that are usually required for solving 'problems' in medicine, most often by individual professionals working alone [20].

Hybrid or 'mixed-mode' approaches in engineering programs typically contain a combination of traditionally taught courses and courses with project-based components that increase in extent, complexity, and student autonomy in later years. A blending of these two approaches appears to be the best way to satisfy industry's needs for independent self-learning, without sacrificing knowledge of engineering fundamentals. This combination of lecture-centred and project-based learning has been welcomed by students, accreditation organizations, and industry. It can be helpful in both undergraduate and postgraduate programs.

Like problem-based learning, project-based learning relies on self-direction and collaboration. Both have a multidisciplinary orientation. Currently, it seems likely that only a relatively small number of courses use projects as the principal learning mode, with teaching of new material eliminated or reduced to a minimum that is directly related to the current project. Projects generally require students to work in small groups with teachers who act as advisers and consultants rather than as formal instructors. They also require students to manage time and avoid duplication of effort. Project work is more directed toward the application of knowledge that has been previously acquired, whereas problem-based learning is directed toward acquisition of new knowledge.

The authors have used a case-study approach for project-based learning in undergraduate and postgraduate courses for many years. Instead of inventing their own projects, they have used material from publications like the Canadian Geotechnical Journal, which provide detailed reports on many successful, and perhaps more importantly, unsuccessful projects. Using these reports as a basis, case study projects ask teams of students to verify the original design and compare them with the reported performance values. The projects involve re-assessing the assumptions made by the original designers and recalculating the analyses made during design. These are then checked against post-construction performance [12].

Table 4 shows a typical instruction sheet for a project assigned in a postgraduate course in slope stability. (We use similar projects in undergraduate courses.) The paper by Krahn et al. [16] referred to in Table 2 describes a failure near Maymont, Saskatchewan. The failure occurred during construction of an engineered cut at the crest of a deep river valley. The cut was needed to achieve adequate grades on the approach road to a new highway bridge. The paper contains information about the soil conditions at the site (Figures 2, 3), stratigraphy, soil properties and ground water potentials, and the geometry of the failure surface (Figure 4).

In confirmatory analyses, our students use modern commercially-available software for stress-deformation, seepage, and slope stability. We typically use SIGMA-W,

Table 4: Typical instructions for a senior-level case study project.

\section{Assignment: 23.711 Slopes Engineering}

$$
\text { Memorandum - Dept. of Highways }
$$

To: $\quad$ Jack Right, Geotechnical Division

From: John Left, Planning Division

Date: $\quad 5^{\text {th }}$ March 1987

Subject: Maymont Slide*

1. I have been thinking again about the Maymont slide

2. Please confirm the details of the re-design you did for me after the initial slide. I would like you to rework your original analysis.

3. Also suggest alternatives that would have been equally successful. I want my people in this office to examine the economics of possible alternative solutions.

* Notes for students: The slide at Maymont SK was described by J.Krahn, R.F. Johnson, D.G.Fredlund, and A.W.Clifton (1979). A highway cut failure in Cretaceous sediments in Maymont, Saskatchewan”. Canadian Geotechnical Journal 16, 703-715.

The assignment is for academic use only. It does not imply criticism of the original engineering team. 


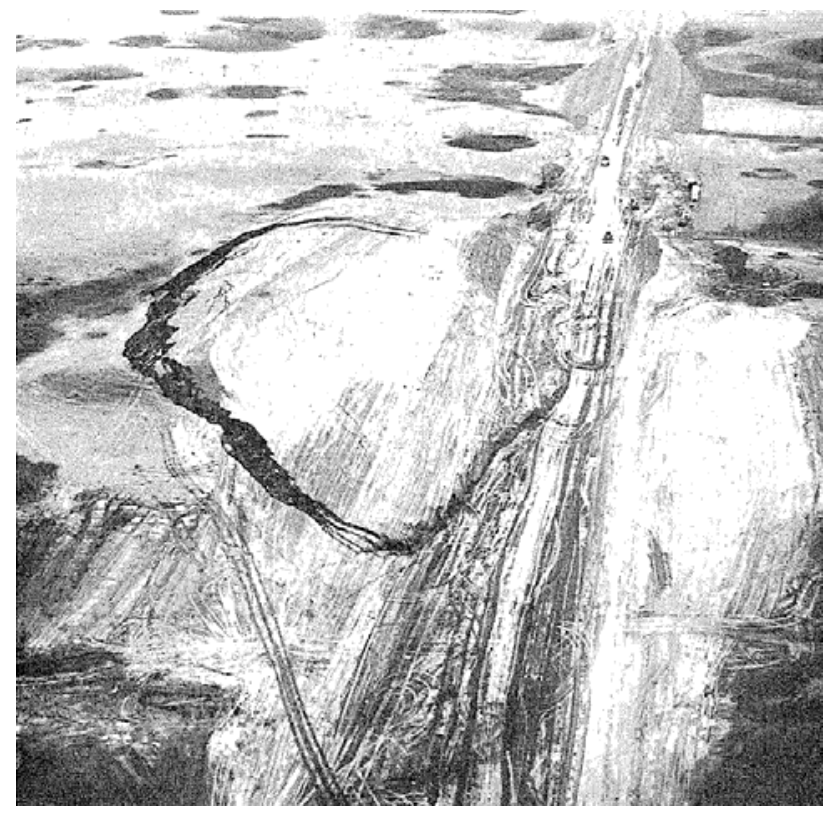

Fig. 2. An oblique aerial view of the Maymont slide [16].

SEEP-W, and SLOPE-W produced by Geo-Slope Inc, Calgary, Alberta in their Geo-Studio suite. This software has the advantage of a simple graphic user interface allowing for easy input of data and coupling of stress, seepage and slope stability analyses. We are careful to ensure that students understand what is going on in the

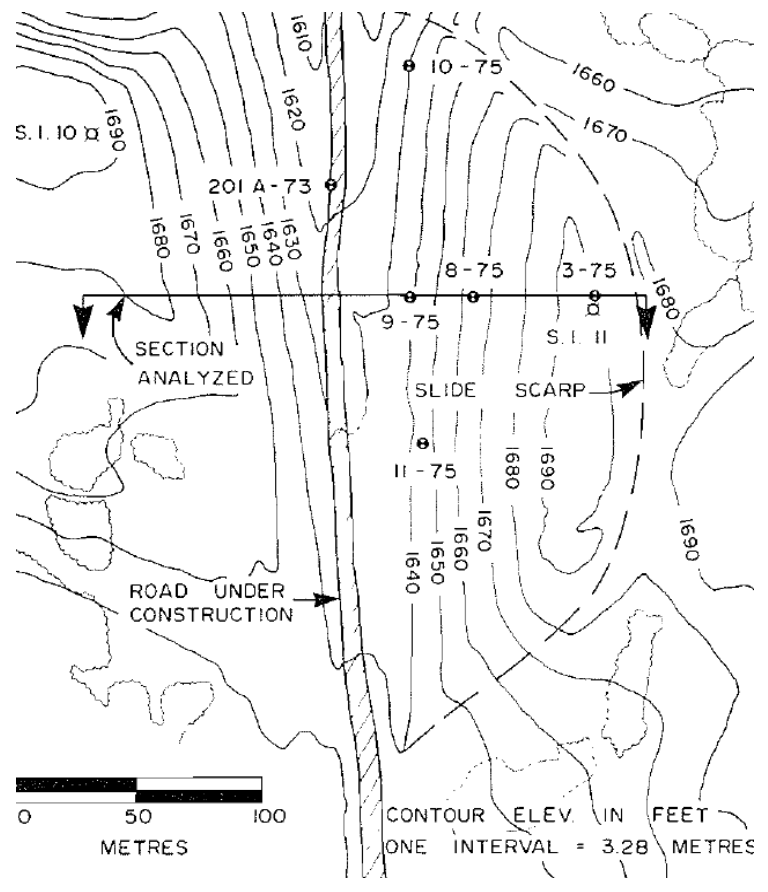

Fig. 3. Contour map of the slide area showing the Locations of the boreholes and section analyzed.

software and what assumptions are being made. This is not simply 'black-box' engineering. Other programs are of course available.

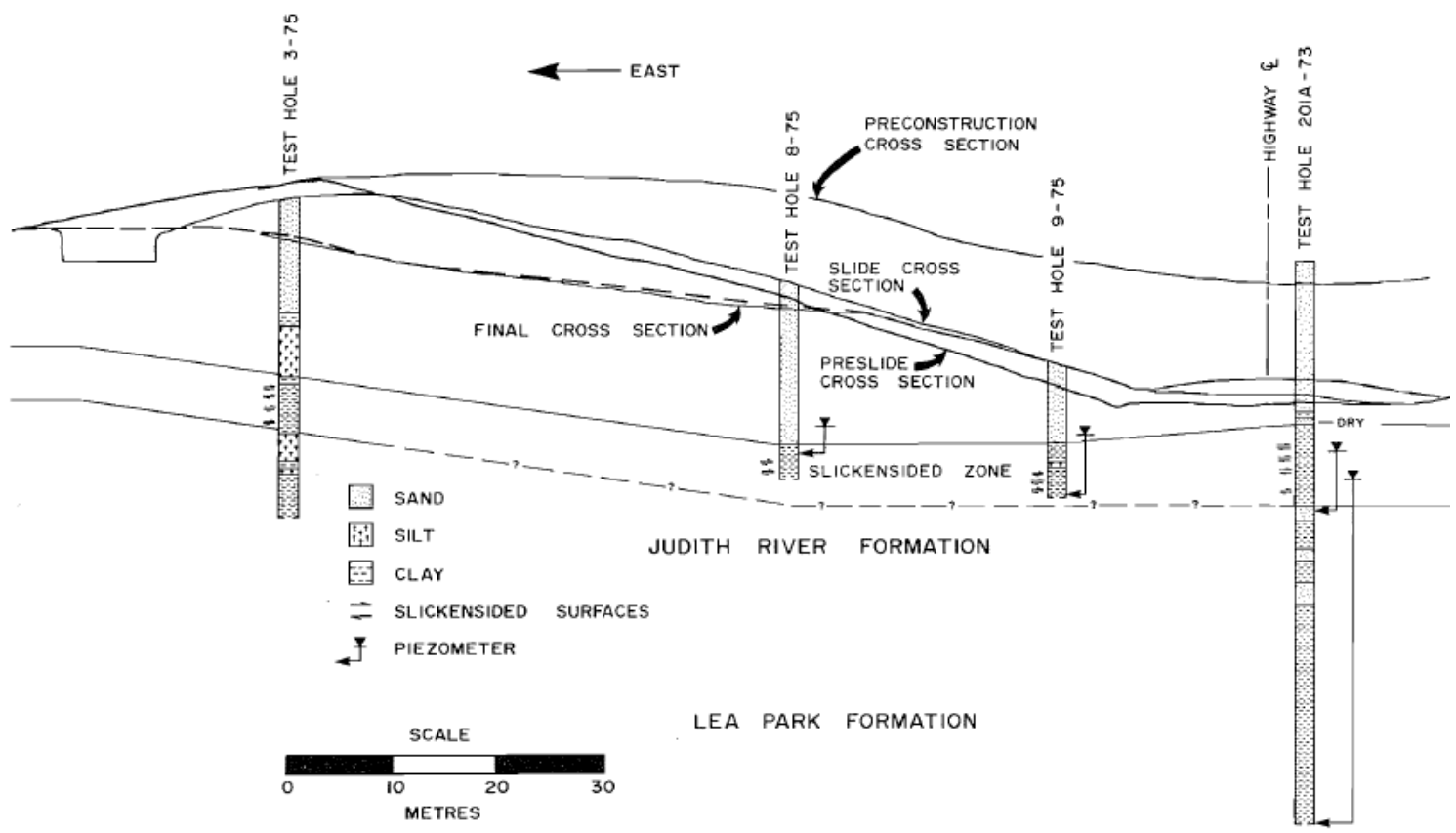

Fig.4. A stratigraphic section of the Maymont slide, together with the pre-slide and final section profiles 
Students are first required to analyse the failed slope using Slope-W. This is considered normal practice. If a failure with a known safety factor of 1.0 can be modeled within $\pm 0.05-0.10$ then there is a strong likelihood that remedial works can also be modeled successfully. Students are also asked to explain why only one side of the cut failed. The published paper makes it clear that the original designers knew that the designed side slopes would be marginally stable. They chose to proceed on the basis that if a slide occurred, it would do so during construction and could be relatively cheaply repaired without significant loss of service.

The project requires group collaboration, an understanding of a broad range of geotechnical issues related to landslides, and an examination of alternative approaches to slope remediation. Students typically gain confidence in their understanding of soil properties and abilities to model slopes successfully.

\section{POSTGRADUATE PROGRAMS}

Preceding sections discussed some features of geotechnical engineering courses in undergraduate civil engineering programs. Following the policies of the Canadian Engineering Accreditation Board, these courses should produce civil engineering graduates with a good general understanding of the role and responsibilities of geotechnical engineers. Hopefully, the courses will be seen as modern, stimulating, and relevant, and will attract good young people into geotechnical practice. They will not, however, produce engineers who can be considered specialists able to take the lead on difficult projects.

It has been estimated that $85 \%$ of the members of the Canadian Geotechnical Society, which we take as a representative sample of geotechnical engineers in Canada, have master's degrees, many of them from 2year programs containing specialist courses and good research which is often publishable. Fifteen percent of geotechnical master's graduates proceed to doctorates. Postgraduate programs can be entered immediately after a first degree in civil, mining, or geological engineering, or after some years in practice. Some students enter postgraduate studies after a degree in geosciences. We note, however, that licensing as a professional engineer or geoscientist depends on having a first degree, not a specialist degree from an accredited program.

What should be the nature of master's programs [19]? In previous sections, we agreed that bachelor's degree programs should be broadly based and should emphasise education and learning. In contrast, master's degrees are increasingly seen as a necessary step towards employability. This means they are no longer simply the 'training in research' that was formerly seen as preparation for a doctorate. Instead, they become the source of the detailed training in specific technologies and design procedures that are needed for practice. They should still reflect the breadth of the discipline. If this is done, master's degrees represent the first level of specialisation and require a larger component of training [11]. This requires that postgraduate courses should be arranged so that graduates can become productive shortly after entering employment. The concept of 'employability' is an important one. Specialist courses can be tailored to the needs of industry and still retain a high level of rigour and intellectual challenge.

There are two types of master's programs in Canadian universities. One, often titled Master of Engineering (MEng), is based principally on coursework. It consists of perhaps 10 to 12 term courses plus a project that may be related to the candidate's experiences in industry, to a design problem, or to a research topic. These programs can often be completed in 12 to 15 months of full-time study and many can be taken part-time. There is rarely financial support from universities for MEng programs, though some employers will sponsor them as professional development.

The second type, usually a Master of Science (MSc) program, has a smaller component of coursework, often 6 to 8 term courses, and a larger research project that usually leads to publication. These MSc programs last 18 to 27 months of full-time study and often provide some financial support. Both types of program are welcomed by employers. Some prefer the larger content of technical instruction in MEng programs, while others value the longer period of guided study and thesis preparation that are major components of MSc programs.

Programs of postgraduate courses tend to be less ordered than undergraduate programs and more sensitive to the interests of individual professors, who have often viewed them in the past as training grounds for doctoral students. This is perhaps unfortunate.

Some years ago, we were criticized at the University of Manitoba for producing master's graduates in geotechnical engineering who knew no hydrogeology (or geoenvironmental engineering, or other favoured topic). In response, we designed a program of four core courses that would be taken by all our master's students. These included Soils Engineering, Rocks Engineering, Groundwater Engineering and Environmental Geotechnology. The courses aimed at providing a broad training in the principal areas of current geotechnical practice. In addition, students took another 2 to 4 courses that provided greater depth in the area of their major project. For example, our students generally took courses in Soil Properties and Behaviour, Glacial Geology and Geomorphology, Soil Chemistry, and Finite Elements. Students of our colleague in Hydrogeology took a different series of electives. The approach requires a sufficient level of staffing to provide the needed range of courses. One solution is to offer courses only in alternate 
years. Staffing becomes an important constraint in small universities. Further work needs to be done to provide opportunities for distance learning.

We also raise the question of program requirements for licensing. If a master's degree is increasingly necessary for employment, should it also be required for licensing? Some countries, notably the United States and the United Kingdom are moving towards requiring master's degrees (or equivalent) for licensing [3][25]. Experience in some UK universities shows there may also be a need for more general master's programs, perhaps centred round project management. The qualifications needed to become licensed as a professional engineer and then to practice in geotechnical engineering remains undecided. This may become an increasingly important issue.

\section{COSTS AND BENEFITS}

A preceding section proposed the strategies 'Forward to the Basics' and 'Employability'. The strategies involve introducing material that provides a good understanding of the basics of the modern scope of the subject. They also involve an emphasis of self-learning, teamwork, and the need for ongoing professional development.

Naturally, the approach involves costs and benefits. The costs to undergraduate programs include less coverage and understanding of material that used to be central to the discipline but has been superseded by modern technologies. It is important that students know and understand the physics and mathematics of the fundamentals, but details of discarded solutions can, and should, be deleted from the program.

For example, compared with some years ago, our students at the University of Manitoba now know less about soil classification, compaction, classic elastic stress distributions, the Swedish Method of Slices for slope analysis, and graphical construction of flow nets. These topics are often handled differently in different companies and in any case are relatively easy to learn if needed. Hand calculations for stress analysis, slope stability, and ground water flow have all been largely superseded by modern numerical analysis. Despite 'pruning' older material, we have had to reduce our students' experience in hands-on laboratory testing and our coverage of routine construction practice.

Obviously, our programs offer clear benefits as well. These include

- good understanding of soil and rock behaviour, using elasto-plasticity where relevant,

- coherent limit equilibrium analysis for slopes, walls and footings,

- computer analysis for slopes, seepage and deformations,
- emphasis on geology, hydrogeology, soil chemistry, geoenvironmental engineering,

- specialty topics like geosynthetics, reinforced earth, soil improvement, etc.

- use of project based learning to develop learning skills, self-motivation, teamwork, confidence and communication.

For us in geotechnical engineering, and presumably also in other disciplines, the twin strategies of 'Forward to the Basics' and 'Employability' are only valid if benefits outweigh the costs. The approach

- provides an improved synthesis of geology, hydrogeology, geochemistry and geophysics in a form that helps an understanding of geotechnical and geoenvironmental engineering in relationship to civil engineering,

- introduces students, academic colleagues and administrators to the 'high tech' nature of modern geotechnics used in modern civil engineering, and

- helps to produce educated, modern engineers who are aware of their responsibilities to their clients and to society.

\section{CONCLUDING COMMENTS - EDUCATION AND TRAINING}

In line with CEAB guidelines, it is important that university programs concentrate on professional engineering and do not spend much time on teaching simple technologies. Engineers need skills that allow them to judge whether work they order is done well. Many of these skills are best learned in practice. Learning is assisted by undergraduate programs that provide a broadly based understanding of what may be loosely called the engineering method.

Functioning as a professional engineer involves a) helping to formulate clients' problems, b) appreciating the range of technical, social, environmental, financial, and scheduling issues that will control the project, and c) working towards a timely, effective, and economic solution. Particularly important are awareness of other peoples' points of view, ability to work collaboratively with teams of fellow professionals, and appreciation of the open-ended nature of the design process. All of these can be, and our view should be, introduced in broadlybased undergraduate programs.

However, in the time available and with the wide range of subjects in typical undergraduate degree programs, it is not then possible to prepare graduates adequately for specialized employment as structural, hydraulics, transportation, environmental or geotechnical engineers. There is simply insufficient time or funding for specialization. An undergraduate degree needs to be an education and not a training. 
Employers, however, want engineers who have specialized training as well as a broad education. This appears to require additional training beyond bachelor level. Increasingly, international bodies that license professional engineers are considering a move to require a postgraduate degree or certificate as the academic qualification for licensing. Some additional years of directed experience are usually also required. It appears unfortunate that Engineers Canada, the federation of provincial licensing bodies, is not participating more actively in these discussions.

\section{Acknowledgements}

Our thanks go to James Blatz, Ken Skaftfeld, Samina Ali.

\section{References}

[1] ABET. 2012. Criteria for Accrediting Engineering Programs 2012-2013. Engineering Accreditation Commission of the Accreditation Board of Engineering and Technology, Baltimore, Maryland. Available at http://www.abet.org/engineeringcriteria-2012-2013/

[2] Alfaro, M., Blatz, J., and Graham, J. 2008. "Refining geotechnical education to reflect modern engineering practice.” Proc., 61st Canadian Geotechnical Conf., Edmonton AB, 21-24 September 2008, 1075-1082.

[3] ASCE. 2004. ASCE Policy Statement 465: Academic Prerequisites for Licensure and Professional Practice. Task Committee on the First Professional Degree, Amer. Soc. of Civil Engineers, Reston VA.

[4] ASCE Body of Knowledge Committee. 2008. Civil Engineering Body of Knowledge for the 21st Century-2nd Edition (BOK2). American Society of Civil Engineers, Reston, Virginia, 181p. Available at http://www.asce.org/professional/educ/

[5] Bilanski, W.K. 2008. The international picture: President's Message. Engineering dimensions, Professional Engineers Ontario (PEO), Jan/Feb 2008.

[6] Burland, J.B. 1987. "The teaching of soil mechanics - a personal view.” The Nash Lecture. Proc. $9^{\text {th }}$ European Conference on Soil Mechanics and Foundations Engineering, Dublin, 3, 1427-1441.

[7] CAE. 1999. Evolution of Engineering Education in Canada. Report of the Canadian Academy of
Engineering, prepared by Task Force chaired by A. Heidebrecht, December 1999. publ.

Canadian Academy of Engineering, Ottawa ON, ISBN 0-96782770-6-3, pp.1-17

[8] Engineers Canada. 2011. Accreditation Criteria and Procedures. Canadian Engineering Accreditation Board. Publ. Engineers Canada, Ottawa ON, pp.90. ISSN 1708-8054.

[9] Feletti, G. 1993. "Inquiry based and problem based learning: How similar are these approaches to nursing and medical education?" Higher Education Research and Development 12: 143-156.

[10] Graham, J. 2000. "Importance of academic staff in the development of undergraduate programs." Invited Keynote Address, Proc. 1st Panamerican Conference on Teaching-Learning Process in Geotechnical Engineering, Nov. 2000. pp.3 - 14. publ. Mexican Soil Mechs. Soc. Oaxaca, Mexico.

[11] Graham, J. and Hachich, W. 2002. Report on Session 1: Teaching of geology, soil mechanics, and rock mechanics at undergraduate level. Proc. 2nd Pan-American Conference on the Teaching and Learning Process in Geotechnical Engineering, Guayaquil, Ecuador, November 2002.

[12] Graham, J. and Kurz, D. 2012. "Case studies - a tool for learning.” Proc. 2012 Canadian Engineering Education Association Conf., Winnipeg MB, June 2012..

[13] Institution of Civil Engineers 2008. Hansard Archives Research, Publications Committee, Select Committee on Education and Skills: Written Evidence available at http://www.publication.parliament.ukk/pa/cm20060 7/cmselect'cemduski/2050205we27.htm

[14] Institution of Engineers, Australia. 1999. Manual for the accreditation of professional engineering programs. Revised 7 Oc. 1999. Canberra: Inst.of Engineers.

[15] Kellar, J.J., Hovey, W., Langerman, M., Howard, S., Simonson, L., Kjerengtroen, L., Stetler, L., Heilhecker, H., Arneson-Meyer, L., Kellogg, S.D. 2000. "A problem based learning approach for freshman engineering.” ASEE/IEEE Frontiers in Education Conference, 18-21 Oct. 2000, Kansas City MO, USA. Session F2G, 7-10. 
[16] Krahn, J., Johnson, R.F., Fredlund, D.G., and Clifton A.W. (1979). “A highway cut failure in Cretaceous sediments in Maymont, Saskatchewan.” Canadian Geotechnical Journal 16, 703-715.

[17] Lee, R.M.K.W., and Kwan, C.-Y. 1997. "The use of problem-based learning in medical education.” Journal of Medical Education 1: 149-157.

[18] Mills, J.E. and Treagust, D.F. 2003. "Engineering education - is problem-based or project-based learing the answer?" Australasian Journal of Engineering Education, eds. N. Scott, R. Hadgraft, and V. Ilic, ISSN 1324-5821, 1-15.

[19] Mitchell, J.K. 1999. “Education in geotechnical engineering - its evolution, current status, and challenges for the 21st century." Keynote Address, Proc. 11th PanAmerican Conf. on Soil Mechanics and Geotechnical Engineering, Fos do Iguassu, Brazil, 3, August 1999.

[20] Perrenet, J.C., Bouhuijs, P.A.J. and Smits, J.G.M.M. 2000. "The suitability of problem-based learning for engineering education: theory and practice.” Teaching in higher education 5, 45-358.

[21] Rugarcia, A., Felder, R.M., Woods, D.R., and Stice, J.E. 2000. "The future of engineering education. 1.
A vision for a new century.” Chemical Engineering Education 34: 16-25.

[22] Saarinen-Rahiika, H. And Binkley, J.M. 1998. "Problem-based learning in physical therapy: a review of the literature and overview of the McMaster University experience.” Physical Therapy 78: 195-207.

[23] SARTOR. 2000. Standards and Routes to Registration: SARTOR ( $3^{\text {rd }}$ ed). Available at http://www.engc.org.uk/registration/sartor.asp

[24] Spaulding, W.B. 1969. "The undergraduate medical curriculum (1969 model): McMaster University.” Canadian Medical Assoc. Journal 100: 659-664.

[25] Townsend, F. 2002. Invited keynote address. Proc. 2nd PanAmerican Conference on the Teaching and Learning Process in Geotechnical Engineering, Guayaquil, Ecuador, November 2002.

[26] Turner, A.K. 2011. "The role of competencyoriented descriptions in geo-engineering.” Proc. $14^{\text {th }}$ Pan-American Conference on Soil Mechanics and Geotechnical Engineering and $64^{\text {th }}$ Canadian Geotechnical Conference, Toronto, ON, Oct. 2011. 